\title{
APLIKASI UNDANG-UNDANG NOMOR 5 TAHUN 1999 TENTANG LARANGAN PRAKTEK MONOPOLI DAN PERSAINGAN USAHA TIDAK SEHAT DALAM KEGIATAN USAHA BUMN
}

\author{
Rahmi Yuniarti \\ Universitas Muhammadiyah Riau, Indonesia, rahmiyuniari@umri.ac.id
}

\begin{abstract}
The role of BUMN (state-owned corporation) as national economic actors must be regulated by a regulation so as not to lead to the establishment of authority or abuse of authority so as not to harm the public interest. UU No. 5 of 1999 on Prohibition of Monopoly and Unhealthy Competition Practices (UU 5/1999), it is stipulated on the role of State-Owned Enterprises in carrying out their business activities related to monopoly rights based on the mandate of Article 33 Paragraph (2) and (3) of the 1945 Constitution. The problems arising from the background are How the Application of UU 5/1999 and How the Effectiveness of Law UU 5/1999. The purpose of this study is to know and analyze the Application of Law No. 5 of 1999 Activities and To know and analyze the Effectiveness of Law from UU 5/1999. This research is normative law research. This type of research is descriptive research. Based on the results of the study, the results were obtained as follows: First, UU 5/1999 essentially binds every business actor in his business activities, with consideration to realize the general welfare, based on Article 51 of UU 5/1999 as one of the businesses are given certain exceptions related to the application of UU 5/1999 in its business activities. The fulfillment of some exclusion criteria for BUMN is contained in the Implementation Guidelines of Article 51 of UU 5/1999, so not all BUMN are granted monopoly rights under Article 51 of UU 5/1999. Granted monopoly rights to BUMN brings the understanding that the management of monopoly activities must also be accounted to the government. Its nature is not merely profit-seeking. The important role of BUMN in the national economy in order to realize the welfare of the people remains the main objective of the business activities carried out by BUMN. Second, there is still a violation of the provisions of UU 5/1999 by BUMN as done by PT. Telkomunikasi Indonesia, Tbk in case number: 02/KPPU-I/2004 concerning The Implementation of International Direct Connection (SLI) by PT. Telecommunications Indonesia, Tbk. At least in such cases shows the low legal culture of PT. Telecommunications Indonesia, Tbk as a state-owned enterprise in realizing the objectives of UU 5/1999 jo UU 19/2003, namely realizing the general welfare, as well as the absence of legal vacancies related to the limitations of kppu authority in the enforcement of administrative and criminal sanctions in $U U 5 / 1999$, causing $U U$ 5/1999 has not been fully effective against business activities conducted by BUMN. Keywords: Monopoly Practices, Unhealthy Business Competition, State Enterprise, $B U M N$
\end{abstract}




\begin{abstract}
Abstrak
Peran Badan Usaha Milik Negara sebagai pelaku ekonomi nasional harus diatur dengan suatu peraturan-undangan agar tidak mengarah pada pelampauan wewenang atau penyelahgunaan wewenang sehingga tidak merugikan kepentingan umum. Dalam Undang-Undang Nomor 5 Tahun 1999 tentang Larangan Praktek Monopoli dan Persaingan Usaha Tidak Sehat, diatur mengenai peranan Badan Usaha Milik Negara dalam menjalankan kegiatan usahanya terkait hak monopoli berdasarkan amanat Pasal 33 Ayat (2) dan (3) UUD 1945. Permasalahan yang timbul dari latar belakang tersebut adalah Bagaimana Aplikasi Undang-Undang Nomor 5 Tahun 1999 Tentang Larangan Praktik Monopoli dan Persaingan Usaha Tidak Sehat Terhadap Kegiatan Usaha BUMN dan Bagaimana Efektivitas Hukum dari Undang-Undang Nomor 5 Tahun 1999 Tentang Larangan Praktik Monopoli dan Persaingan Usaha Tidak Sehat Terhadap Kegiatan Usaha BUMN. Tujuan penelitian ini adalah untuk mengetahui dan menganalisis Aplikasi Undang-Undang Nomor 5 Tahun 1999 Tentang Larangan Praktik Monopoli dan Persaingan Usaha Tidak Sehat Terhadap Kegiatan Usaha BUMN dan Untuk mengetahui dan menganalisis Efektivitas Hukum dari Undang-Undang Nomor 5 Tahun 1999 Tentang Larangan Praktik Monopoli dan Persaingan Usaha Tidak Sehat Terhadap Kegiatan Usaha BUMN. Penelitian ini merupakan penelitian hukum normatif. Tipe penelitian ini adalah penelitian deskriptif. Berdasarkan hasil penelitian, maka diperoleh hasil sebagai berikut : Pertama, UU No. 5 Tahun 1999 tentang Larangan Praktik Monopoli dan Persaingan Usaha Tidak Sehat hakikatnya mengikat setiap pelaku usaha dalam kegiatan usahanya, dengan pertimbangan untuk mewujudkan kesejahteraan umum, berdasarkan Pasal 51 UU No. 5 Tahun 1999, BUMN sebagai salah satu pelaku usaha diberikan pengecualian tertentu terkait penerapan UU No. 5 tahun 1999 dalam kegiatan usahanya. Pemenuhan beberapa kriteria pengecualian terhadap BUMN terdapat pada Pedoman Pelaksanaan Pasal 51 UU No. 5 Tahun 1999, jadi tidak semua BUMN diberikan hak monopoli berdasarkan Pasal 51 UU No. 5 Tahun 1999. Diberikan hak monopoli kepada BUMN membawa pengertian bahwa pengelolaan kegiatan monopolinya pun harus dipertanggungjawabkan pada pemerintah. Sifatnya tidak semata-mata mencari keuntungan. Peran penting yang dimiliki BUMN dalam perekonomian nasional guna mewujudkan kesejahteraan rakyat tetap menjadi tujuan pokok dari kegiatan usaha yang dijalankan BUMN. Kedua, Masih terdapatnya pelanggaran terhadap ketentuan UU No. 5 tahun 1999 tentang Larangan Praktik Monopoli dan Pesaingan Usaha Tidak Sehat oleh BUMN sebagaimana dilakukan oleh PT.Telkomunikasi Indonesia, Tbk dalam perkara nomor: 02/KPPU-I/2004 Tentang Penyelenggaraan Sambungan Langsung Internasional (SLI) oleh PT. Telekomunikasi Indonesia, Tbk. Setidaknya dalam kasus tersebut menunjukan masih rendahnya budaya hukum PT. Telekomunikasi Indonesia, Tbk sebagai BUMN dalam mewujudkan tujuan UU No. 5 tahun 1999 jo UU 19 tahun 2003 yakni mewujudkan kesejahteraan umum, serta masih terdapatnya kekosongan hukum terkait keterbatasan kewenangan KPPU dalam penegakan sanksi administratif maupun pidana dalam UU No. 5 tahun 1999, menyebabkan UU No. 5 tahun 1999 belum sepenuhnya berlaku efektif terhadap kegiatan usaha yang dilakukan BUMN.
\end{abstract}


Kata Kunci : Praktek Monopoli, Persaingan Usaha Tidak Sehat, BUMN

\section{Pendahuluan}

Salah satu ciri bisnis atau perekonomian yang paling menonjol pada era globalisasi adalah moving quickly. Perubahan dan pergeseran yang cepat dalam era yang super industrialis sekarang telah mengantar umat manusia ke suatu kehidupan dunia tanpa batas (borderless world). ${ }^{1}$ Ini berarti bangsa Indonesia tidak dapat menampik kenyataan bahwa corak dan konsep pasar bebas dan persaingan bebas dalam segala bentuk terpaksa diterima sebagai kenyataan. ${ }^{2}$ Situasi dan kondisi tersebut memberikan tuntutan untuk mencermati dan menata kembali

\footnotetext{
${ }^{1}$ Keinichi Ohmae, Borderless World, dalam, Suyud Margono, Penyelesaian Sengketa Bisnis Alternative Dispiute Resolutions (ADR) Teknik \& strategi dalam Negosiasi, Mediasi \& Arbritase, Ghalia Indonesia, Bogor, 2010, hlm. 3.

${ }^{2}$ Ibid, hlm. 3.
}

kegiatan usaha di Indonesia, agar dunia usaha dapat tumbuh serta berkembang secara sehat dan benar, sehingga tercipta iklim persaingan usaha yang sehat serta terhindarnya pemusatan kekuatan ekonomi pada perorangan atau kelompok tertentu, antara lain dalam bentuk praktik monopoli dan persaingan usaha tidak sehat yang merugikan masyarakat dan bertentangan dengan cita-cita keadilan sosial. $^{3}$ Untuk menjawab tantangan pada era persaingan usaha yang bebas, pada tahun 1999 pemerintah membuat dan memberlakukan Undang-Undang Nomor 5 Tahun 1999 Tentang

\footnotetext{
${ }^{3}$ Devi Meyliana, Hukum Persaingan Usaha :Studi Konsep Pembuktian Terhadap Perjanjian Penetapan Harga dalam Persaingan Usaha, Setara Press, Malang, 2013, hlm.12. ; Lihat juga penjelasan umum Undang-Undang Nomor 5 Tahun 1999 Tentang Larangan Praktek Monopoli dan Persaingan Usaha Tidak Sehat.
} 
Larangan Praktik Monopoli dan penting dalam mewujudkan Persaingan Usaha Tidak Sehat. kesejahteraan masyarakat sebagaimana Dengan demikian kelahiran Undang- diamanatkan dalam Pasal 33 UndangUndang Nomor 5 Tahun 1999 ini Undang Dasar 1945..$^{5}$ Pasal 33 UUD dimaksudkan untuk memberikan 1945 menghendaki adanya monopoli jaminan kepastian hukum dan perlindungan yang sama kepada setiap pelaku usaha dalam berusaha, dengan cara mencegah timbulnya praktikpraktik monopoli dan atau persaingan usaha yang tidak sehat lainnya dengan harapan dapat menciptakan iklim usaha yag kondusif, dimana setiap pelaku usaha dapat bersaing secara sehat dan wajar. ${ }^{4}$ Pemerintah melakukan kegiatan usaha meletakan mandat tersebut kepada Badan Usaha Milik Negara (BUMN). BUMN merupakan salah satu pelaku kegiatan ekonomi dalam perekonomian Indonesia disamping usaha swasta dan koperasi dan mempunyai peran

${ }^{5}$ Djuhaendah Hasan, Pengelolaan Kekayaan Badan Usaha Milik Negara dan Permasalahannya, dalam Kompilasi Hukum Bisnis dalam Rangka Purnabakti Prof.Dr.H.Man Sastrawidjadja. S.H.,S.U., CV.Keni, Bandung, 2012, hlm.26.

${ }^{6}$ Asep Suryadi, Pengecualian Penerapan Undang-Undang Nomor 5 Tahun 1999 Tentang Larangan Praktek Monopoli dan Persaingan Usaha Tidak Sehat Terhadap Perjanjian yang Berkaitan dengan Waralaba, dalam Kompilasi Hukum Bisnis Dalam Rangka Purna Bakti Prof. Dr. Man Sastrawidjadja,S.H., S.U., hlm. 435.

${ }^{7}$ Janus $\quad$ Sidabalok, Hukum Perusahaan Analisis Terhadap Pengaturan 
operasional perusahaan negara yang dalam konsiderannya diakui bahwa Badan Usaha Milik Negara merupakan salah satu pelaku ekonomi dalam perekonomian nasional berdasarkan demokrasi dan mempunyai peran penting dalam perekonomian nasional guna mewujudkan kesejahteraan rakyat. ${ }^{8}$ Salah satu bentuk perbuatan administrasi negara dalam kegiatan ekonomi yang bersifat yuridis adalah pengaturan monopoli dan/atau pemusatan kegiatan yang berkaitan dengan produksi dan pemasaran atas barang dan/atau jasa yang menguasai hajat hidup orang banyak serta cabang produksi yang penting bagi negara sebagai upaya pengembangan usaha yang sehat dan peningkatan daya saing usaha diperlukan agar dapat

Peran Perusahaan Dalam Pembangunanan Ekonomi Nasional Di Indonesia, Nuasa Aulia Bandung, 2012, hlm. 41.

${ }^{8}$ Ibid., hlm. 47. membangun kembali kepercayaan masyarakat yang pada akhirnya dapat mendorong pertumbuhan ekonomi nasional. $^{9}$

\section{Peran Badan Usaha Milik} Negara sebagai pelaku ekonomi nasional harus diatur dengan suatu peraturan-undangan agar tidak mengarah pada pelampauan wewenang atau penyelahgunaan wewenang sehingga tidak merugikan kepentingan umum. Dalam Undang-Undang Nomor 5 Tahun 1999 tentang Larangan Praktek Monopoli dan Persaingan Usaha Tidak Sehat, diatur mengenai peranan Badan Usaha Milik Negara dalam menjalankan kegiatan usahanya. Menurut Pasal 51 Undang-Undang Nomor 5 Tahun 1999 menyatakan :

"Monopoli dan atau pemusatan kegiatan yang berkaitan dengan

${ }^{9}$ Isis Ikhwansyah, Hukum Persaingan Usaha dalam Implementasi Teori dan Praktik, Unpad Press, Bandung, 2010, hlm. 3. 
produksi dan atau pemasaran barang dan atau jasa yang menguasai hajat hidup orang banyak serta caban-cabang produksi yang penting bagi negara diatur dengan undangundang dan diselenggarakan oleh Badan Usaha Milik Negara dan atau badan atau lembaga yang dibentuk atau ditunjuk oleh Pemerintah."

Perlunya dibentuk Pedoman Pasal 51 Undang-Undang Nomor 5 Tahun 1999 agar dapat mengurangi praktik monopoli dan persaingan usaha tidak sehat yang dilakukan Badan Usaha Milik Negara. Seperti contoh, dalam perkara nomor: $02 / \mathrm{KPPU}-$ I/2004 Tentang Penyelenggaraan Sambungan Langsung Internasional (SLI) oleh PT. Telekomunikasi Indonesia, Tbk. Berdasarkan laporan hasil monitoring yang dilakukan oleh tim monitoring terdapat adanya dugaan tindakan pemblokiran terhadap Sambungan Langsung Internasional (selanjutnya disebut SLI) kode akses 001 dan 008 milik PT. Indosat. PT. Telkom telah melakukan perjanjian dengan penyelenggara warung telkom yang memuat klausula yang berakibat pada tidak tersedianya jasa telepon internasional selain produk jasa PT. Telkom.

Hal ini menjadi menarik untuk dibahas, karena erat kaitanya dengan pembangunan ekonomi Indonesia pada pasar persaingan bebas. Pembangunan ekonomi tidak bisa dipisahkan dari hukum, bahwa antara sistem hukum dan sistem ekonomi suatu Negara terdapat hubungan yang sangat erat dan pengaruh timbal balik. ${ }^{10}$

\section{${ }^{10}$ Sunaryati Hartono, Hukum} Ekonomi Pembangunan Indonesia, Binacipta, Bandung, 1988, hlm. 6. 
Berkaitan dengan Undang-

Undang Nomor 5 Tahun 1999 Tentang

Larangan Praktik Monopoli dan

Persaingan Usaha Tidak Sehat penulis

hendak mengkaji bagaimana

penerapannya pada BUMN.

Berdasarkan uraian diatas penulis

mengkaji permasalahan dengan judul

“Aplikasi Undang-Undang Nomor 5

Tahun 1995 Tentang Larangan

Praktik Monopoli dan Persaingan

Usaha Tidak Sehat dalam Kegiatan

Usaha BUMN".

\section{Rumusan Masalah}

Berdasarkan uraian latar

belakang yang telah dipaparkan, terdapat identifikasi masalah sebagai berikut :

1. Bagaimana Aplikasi UndangUndang Nomor 5 Tahun 1999 Tentang Larangan Praktik Monopoli dan Persaingan Usaha
Tidak Sehat Terhadap Kegiatan Usaha BUMN?

2. Bagaimana Efektivitas Hukum dari Undang-Undang Nomor 5 Tahun 1999 Tentang Larangan Praktik Monopoli dan Persaingan Usaha Tidak Sehat Terhadap Kegiatan Usaha BUMN?

\section{Tujuan Penelitian}

Adapun tujuan dari kajian permasalahan pada tulisan ini adalah :

1. Untuk mengetahui dan menganalisis Aplikasi UndangUndang Nomor 5 Tahun 1999 Tentang Larangan Praktik Monopoli dan Persaingan Usaha Tidak Sehat Terhadap Kegiatan Usaha BUMN 
2. Untuk mengetahui dan sebagai norma atau kaidah yang menganalisis $\quad$ Efektivitas berlaku dalam masyarakat dan menjadi Hukum dari Undang-Undang acuan perilaku bagi setiap orang. Nomor 5 Tahun 1999 Tentang Penelitian ini memfokuskan pada Larangan Praktik Monopoli Aplikasi Undang-Undang Nomor 5 dan Persaingan Usaha Tidak Tahun 1995 Tentang Larangan Praktik Sehat Terhadap Kegiatan Usaha BUMN

Monopoli dan Persaingan Usaha Tidak Sehat dalam Kegiatan Usaha BUMN. Tipe penelitian ini adalah penelitian

\section{Metode Penelitian}

Penelitian hukum merupakan kegiatan ilmiah yang didasarkan pada metode, sistematika, dan pemikiran tertentu, yang bertujuan untuk mempelajari satu atau beberapa gejala hukum tertentu, dengan jalan menganalisisnya. ${ }^{11}$ Jenis penelitian yang digunakan penulis dalam penelitian ini adalah bersifat penelitian hukum normatif . Penelitian hukum normatif, yaitu penelitian yang mengkaji hukum yang dikonsepkan

11 Abdulkadir Muhammad, Hukum dan Penelitian Hukum, PT Citra Aditya Bakti, Bandung, 2004, hlm. 52.

deskriptif. Menurut Abdulkadir Muhammad, penelitian hukum deskriptif bersifat pemaparan dan bertujuan untuk memperoleh gambaran (deskriptif) lengkap tentang keadaan hukum yang berlaku di tempat tertentu dan pada saat tertentu yang terjadi dalam masyarakat. Pendekatan masalah merupakan proses pemecahan atau penyelesaian masalah melalui tahap-tahap yang telah ditentukan, sehingga mencapai tujuan penelitian. Penelitian ini akan menganalisis bagaimana Aplikasi 
Undang-Undang Nomor 5 Tahun 1995

Tentang Larangan Praktik Monopoli

dan Persaingan Usaha Tidak Sehat dalam Kegiatan Usaha BUMN. Terkait

dengan tinjauan hukum sering disebut juga tinjauan yuridis (legal review) adalah tingkatan kedua yang digunakan peneliti dalam kajian substansi hukum. Pada tipe tinjauan yuridis, peneliti membahas mengenai Aplikasi Undang-Undang Nomor 5 Tahun 1995 Tentang Larangan Praktik Monopoli dan Persaingan Usaha Tidak Sehat dalam Kegiatan Usaha BUMN. Pengumpulan data dilakukan dengan studi pustaka yang meliputi sumber primer, yaitu perundang-undangan yang relevan dengan permasalahan. Sumber sekunder, yaitu buku-buku literatur ilmu hukum beserta tulisantulisan hukum lainnya yang relevan dengan permasalahan. ${ }^{12}$ Studi pustaka dilakukan melalui tahap-tahap identifikasi pustaka sumber data, identifikasi bahan hukum yang diperlukan, dan inventarisasi bahan hukum (data) yang diperlukan tersebut. Data yang terkumpul kemudian diolah melalui tahap pemeriksaan (editing), penandaan (coding), penyusunan (reconstructing), sistematisasi berdasarkan pokok bahasan dan subpokok bahasan yang di identifikasi dari rumusan masalah (systematizing), yang berkaitan dengan pokok bahasan yang diteliti yaitu Aplikasi Undang-Undang Nomor 5 Tahun 1995 Tentang Larangan Praktik Monopoli dan Persaingan Usaha Tidak Sehat dalam Kegiatan Usaha BUMN.

Hasil Penelitian dan Pembahasan
A. Penerapan Undang-Undang Nomor 5 Tahun 1999 tentang Larangan Praktik Monopoli dan Persaingan Usaha Tidak Sehat terhadap

\footnotetext{
${ }^{12}$ Ibid., hlm. 192.
} 


\section{Kegiatan Usaha Badan Usaha Milik Negara}

Undang-Undang Nomor 5 Tahun

1999 tentang Larangan Praktik

Monopoli dan Persaingan Usaha

Tidak Sehat secara umum bertujuan

untuk memelihara pasar kompetitif

dari pengaruh kesepakatan dan

konsipirasi yang cenderung

mengurangi dan atau menghilangkan

persaingan. ${ }^{13}$ Menghindari dan

memelihara agar pasar dapat berjalan

kompetitif, UU No.5 Tahun 1999

secara garis besar mengatur 6 (enam)

hal sebagai berikut ${ }^{14}$ :

1. Pertama, Pengertian umum tentang apa yang dimaksud dengan istilah monopoli, praktik monopoli, pemusatan kekuatan ekonomi, posisi dominan pelaku usaha, persaingan usaha tidak sehat, persengkongkolan, pasar, struktur pasar, perilaku pasar, pangsa persengkongkolan, pasar, struktur pasar, perilaku

${ }^{13}$ Isis Ikhwansyah, Hukum Persaingan Usaha dalam Implementasi Teori dan Praktik, Unpad Press, Bandung, 2010, hlm. 37.

${ }^{14}$ Ibid., hlm. 26. pasar, pangsa pasar, konsumen, barang dan jasa.

2. Kedua, pengaturan larangan untuk melakukan praktik oligopoli.

3. Ketiga, pengaturan mengenai larangan penetapan harga (price fixing, price discriminatiom, dan predatory price fixing).

4. Keempat, pengaturan mengenai larangan untuk melakukan tindakan boikot yang dapat mencegah pesaing baru untuk memasuki pasar.

5. Kelima, pengaturan mengenai larangan melakukan perjanjian untuk menciptakan kartel.

6. Keenam, pengaturan mengenai larangan melakukan tindakan yang bersifat oligopsoni (larangan untuk melakukan tindakan yang bertujuan untuk menguasai pembelian atau pasokan barang dan jasa dengan tujuan untuk mengendalikan harga) yang akan mengakibatkan praktik monopoli atau persaingan curang.

Ketentuan tersebut dalam UU No. 5 Tahun 1999 pada hakikatnya mengatur dan mengikat secara umum, dalam artian mengatur dan mengikat setiap pelaku usaha (perusahaan) yang 
melakukan usaha di Indonesia, dalam hal ini termasuk juga mengikat BUMN sebagai salah satu pelaku usaha. Praktiknya, BUMN sebagai pelaku usaha dianggap banyak kalangan melakukan monopoli dalam sektor/cabang-cabang produksi tertentu, seperti Migas oleh PT. Pertamina dan Telekomunikasi oleh PT.Telkom Indonesia. Pendapat yang demikian adalah wajar dan tidak dapat dipungkiri, hal mana mengingat kegiatan usaha yang dilakukan oleh BUMN tersebut dianggap memenuhi ciri-ciri monopoli sebagai berikut $:^{15}$ :

1. Terdapat pemusatan ekonomi oleh satu atau lebih pengusaha,

2. Mengakibatkan dikuasainya produksi dan atau pemasaran atas barang dan atas jasa tertentu,

3. Menimbulkan persaingan usaha tidak sehat dan merugikan kepentingan umum.

\footnotetext{
${ }^{15}$ Ibid., hlm. 27.
}

Hak Monopoli pada BUMN dalam kegiatan usahanya ternyata bukan tanpa dasar hukum. Tindakan hukum BUMN yang melakukan monopoli dalam sektor atau cabang produksi tertentu adalah sesuatu yang diperbolehkan oleh UU 5 tahun 1999. UU 5 tahun 1999 ternyata memberikan pengecualian tertentu akan keberlakuan UU 5 tahun 1999 terhadap BUMN. Berdasarkan Penjelasan Pedoman Pelaksanaan Pasal 51 Undang-Undang Nomor 5 Tahun 1999 tentang Larangan Praktik Monopoli dan Persaingan Usaha Tidak Sehat, pengecualian ini diberikan kepada BUMN dalam melakukan kegiatan usahanya atas pertimbangan :

1. Bahwa Pancasila sebagai dasar filosofis sistem ekonomi indonesia mengamanatkan agar perekonomian Indonesia dibangun atas asas 
Kerakyatan, maksudnya mengutamakan kehidupan ekonomi rakyat dan hajat hidup orang banyak. ${ }^{16}$

2. Bawa dengan mengingat Pasal 33 ayat (2) dan (3) UUD 1945 maka Negara perlu membentuk suatu badan hukum privat untuk mengelola cabang-cabang produksi yang menguasai hidup orang banyak.

3. Mewujudkan sistem demokrasi ekonomi yang dianut Indonesia, Demokrasi Ekonomi dimana salah satu ciri demokrasi ekonomi mengharuskan Cabangcabang produksi yang penting bagi Negara dan menguasai hajat hidup orang banyak dikuaswai oleh Negara. ${ }^{17}$

4. Bahwa Tujuan UU 51999 salah satunya adalah menjaga kepentingan umum dan meningkatkan efisiensi ekonomi nasional sebagai salah satu upaya untuk meningkatkan kesejahteraan rakyat;

5. Bahwa peran BUMN sebagaimana diatur dalam konsiderans UU No 19 tahun 1999 yang salah satunya BUMN adalah mewujudkan kesejahteraan umum.

Mempertimbangkan hal-hal tersebut diatas, para pembentuk

\footnotetext{
${ }^{16}$ Suroso, dalam Ibid.

${ }^{17}$ Cornelis Rintuh, dalam, Ibid, hlm. 42.
}

undang-undang memasukan ketentuan Pasal 51. Pasal 51 memberi dasar hukum kepada BUMN untuk dapat melakukan praktik monopoli sekaligus mendapatkan pengecualian tertentu dalam keberlakuan UU 5 tahun 1999 dalam kegiatan usahanya. Pasal 51 memberikan weweang kepada BUMN untuk melakukan monopoli dan atau pemusatan kegiatan yang berkaitan dengan produksi dan atau pemasaran barang dan atau jasa yang menguasai hajat hidup orang banyak serta cabangcabang produksi yang penting bagi negara.

Pelaksanaan Pasal 51 UU No. 5 tahun 1999 oleh BUMN harus dijalankan secara bertanggungjawab, tidak boleh ditafsirkan secara sewenang-wenang. Berdasarkan teori hukum dan penafsiran sistematis 
terhadap unsur produksi dan/atau pemasaran barang dan/atau jasa yang menguasai hajat hidup orang banyak, menurut Pedoman Pelaksanaan Pasal 51 UU No. 5 Tahun 1999 harus diartikan sebagai fungsi :

1. Alokasi, yang ditujukan pada barang atau jasa yang berasal dari sumber daya alam yang dikuasai negara untuk dimanfaatkan bagi sebesarbesarnya kemakmuran rakyat,

2. Distribusi, yang diarahkan pada barang dan/atau jasa yang dibutuhkan secara pokok oleh masyarakat, tetapi pada suatu waktu tertentu atau terus menerus tidak dapat dipenuhi pasar, dan atau

3. Stabilisasi, yang berkaitan dengan barang dan/atau jasa yang harus disediakan untuk kepentingan umum, seperti barang dan/atau jasa dalam bidang pertahanan keamanan, moneter, dan fiskal, yang mengharuskan pengaturan dan pengawasan bersifat khusus.

Selanjutnya, pengertian cabangcabang produksi yang penting bagi negara dalam ragam usaha produksi atau penyediaan barang dan atau jasa sebagaimana dimaksud Pasal 51 UU 5 Tahun 1999 berdasarkan Pedoman Pelaksanaan Pasal 51 tersebut, dapat diartikan memiliki sifat :

1. Srategis, yaitu cabang produksi atas barang dan/atau jasa yang secara langsung melindungi kepentingan pertahanan negara dan menjaga kemanan nasional; atau

2. Finansial, yaitu cabang produksi yang berkaitan erat dengan pembuatan barang dan/atau jasa untuk kestabilan moneter dan jaminan perpajakan, dan sektor jasa keuangan yang dimanfaatkan untuk kepentingan umum.

Uraian di atas merupakan syarat legal dari negara untuk melakukan monopoli dan/atau pemusatan kegiatan atas barang dan/atau jasa yang menguasai hajat hidup orang banyak serta cabangcabang produksi yang penting bagi negara oleh BUMN. Diberikan hak monopoli kepada BUMN membawa 
pengertian bahwa pengelolaan kegiatan monopolinya pun harus dipertanggungjawabkan pada pemerintah. Sifatnya tidak sematamata mencari keuntungan. Peran penting yang dimiliki BUMN dalam perekonomian nasional guna mewujudkan kesejahteraan rakyat tetap menjadi tujuan pokok dari kegiatan usaha yang dijalankan BUMN.

\section{B. Efektivitas Penerapan Undang- Undang No.5 Tahun 1999 tentang Larangan Praktik Monopoli dan Persaingan Usaha Tidak Sehat Terhadap Kegiatan Usaha Badan Usaha Milik Negara}

Seiring dengan berlakunya Undang-Undang No. 19 Perpu tahun 1960, menandakan masuknya era baru dalam perusahaan negara di
Indonesia $^{18}$. Pasal 1 UU No. 19 Perpu tahun 1960 dijelaskan bahwa perusahaan negara adalah semua perusahaan dalam bentuk apapun yang modal-modalnya untuk seluruhnya merupakan kekayaan negara Republik Indonesia, kecuali ditentukan lain oleh Undang-undang. UU No. 19 Perpu tahun 1960 kemudian ditetapkan menjadi Undang-Undang No. 9 tahun 1969 tentang Bentuk-bentuk Badan Usaha Milik Negara.

Berdasarkan UU No. 9 tahun 1969 BUMN dapat berbentuk, Perusahaan Jawatan, Perusahaan Umum, Perusahaan Perseroang. Terjadi perubahan yang mendasar dalam pengelolaan BUMN sejak tahun $2003^{19}$, hal ini terjadi seiring dengan berlakunya Undang-Undang No. 19

\footnotetext{
${ }^{18}$ Santosa Sembiring, Hukum Dagang, hlm.58. PT. Citra Aditya Bakti, Bandung, 2015,

${ }^{19}$ Ibid., hlm.59.
} 
tahun 2003 tentang Badan Usaha Milik

Negara. Perubahan mendasar dalam

pengelolaan BUMN terjadi karena

setelah berlakunya UU No.19 tahun

2003 bentuk-bentuk BUMN tidak lagi

dalam bentuk perjan, perum dan

Persero, akan tetapi bentuk BUMN

yang baru adalah Persero dalam

bentuk Perseroan Terbatas (PT) dan

Perum.

BUMN memiliki peran strategis

dalam perekonomian Indonesia.

Adanya perubahan pengaturan BUMN

dari UU No.9 tahun 1986 kedalam UU

No.19 Tahun 2003 BUMN tidak lain

untuk mengoptimalkan peran BUMN

dalam perekonomian Indonesia guna

mewujudkan kesejahteraan umum

sebagaimana amanat konstitusi. $^{20}$

BUMN dalam rangka mewujudkan

kesejahteraan masyarakat diberikan

${ }^{20}$ Huruf (b) Konsiderans UU No.19 wewenang khusus oleh undangundang untuk mengelola cabangcabang produksi yang menyangkut hajat hidup orang banyak. Secara hukum, meskipun setelah berlakunya UU No.19 tahun 2003 tentang BUMN, BUMN dimungkinkan dapat berbentuk Perseroan (PT Persero), yang juga bertujuan mengejar keuntungan guna meningkatkan nilai perusahaan, akan tetapi tidak boleh meningkalkan tugas dan fungsi BUMN pokok lainnya yakni meningkatkan kesejahteraan masyarakat.

Diberikannya wewenang khusus oleh undang-undang kepada BUMN untuk mengelola dan menguasai cabang-cabang produksi yang menguasai hajat hidup orang banyak, membawa konsekuensi hukum yakni BUMN mendapat pengecualian tertentu dalam keberlakuan beberapa peraturan perundang-undangan 
nasional dalam kegiatan usahanya, maksudnya Peraturan perundangundangan nasional yang seharusnya mengikat Perseroan Terbatas (termasuk BUMN dalam bentuk PT), akan tetapi BUMN dikecualikan dalam keberlakuannya. Pengecualian tersebut adalah sebagai perwujudan sistem ekonomi demokrasi yang dianut indonesia yang mengharuskan bahwa cabang-cabang produksi yang penting bagi Negara dan menguasai hajat hidup orang banyak dikuaswai oleh Negara. $^{21}$

\section{Salah satu Peraturan}

Perundang-undangan nasional yang memberikan pengecualian keberlakuannya kepada BUMN bentuk PT adalah Undang-Undang Nomor 5 Tahun 1999 tentang Larangan Praktek Monopoli dan Persaingan Usaha Tidak

\footnotetext{
${ }^{21}$ Cornelis Rintuh, dalam, Ibid, hlm. 42.
}

Sehat. Prinsipnya UU No.5 tahun 1999 berlaku dan mengikat kepada setiap pelaku usaha (perusahaan) baik pelaku usaha yang tidak berbadan hukum maupun pelaku usaha yang berbadan hukum dalam bentuk apapun. BUMN Persero dalam bentuk PT ternyata mendapat pengeculian keberlakuan UU 5 tahun 1999 tersebut dengan tujuan agar BUMN lebih optimal dalam menjalankan tugasnya mewujudkan kesejahteraan umum. Pengecualian keberlakuan UU No.5 tahun 1999 terhadap BUMN adalah berdasarkan Pasal 51.

Pasal 51 UU No. 5 tahun 1999 memberikan perlindungan dan mendorong optimalisasi peran dan fungsi BUMN dalam meningkatkan kesejahteraan umum sebagaimana amanat konstitusi, oleh karenanya hendaknya pengecualian yang 
diberikan undang-undang ini

dijalankan dengan penuh

tanggungjawab oleh setiap BUMN.

Mengingat hakikat dari Pasal $51 \mathrm{UU}$

No. 5 tahun 1999 tersebut, Pasal 51

UU No. 5 tahun 1999 hendaknya harus

berlaku efektif terhadap tindakan atau

realita hukum yang dilakukan BUMN,

sehingga dapat diketahui apakah suatu

kaidah hukum berhasil atau gagal

mencapai tujuannya.

Menjamin agar UU No. 5 tahun

1999 berlaku efektif terhadap BUMN

dalam kegiatan usaha BUMN, Faktor-

faktor efektifitas hukum sebagai

berikut haruslah terpenuhi secara keseluruhan ${ }^{22}$ :

1. Faktor hukumnya sendiri

2. Faktor penegak hukum

3. Faktor sarana atau fasilitas yang mendukung penegakan hukum

4. Faktor masyarakat

5. Faktor kebudayaan

\footnotetext{
${ }^{22}$ Soerjono Soekanto, Op.Cit., hlm.8.
}

Praktiknya, tidak

sedikit BUMN yang

memanfaatkan

pengecualian Pasal 51 No.

UU 5 tahun 1999 secara

tidak bertanggungjawab

dan semata-mata mencari

keuntungan guna

meningkatkan nilai

perusahaan, bukan untuk

meningkatkan

kesejahteraan umum.

Contohnya pada Putusan

KPPU Nomor 02/KPPU-

I/2004

Tentang

Penyelenggaraan

Sambungan Langsung

Internasional (SLI) oleh

PT. Telekomunikasi

Indonesia, Tbk. PT

Telekomunikasi Indonesia,

Tbk. (selanjutnya disingkat

PT Telkom) bertindak 
sebagai Terlapor melawan

Komisi Pengawas

Persaingan Usaha

Republik Indonesia

(selanjutnya disebut

KPPU) sebagai komisi

yang memeriksa dugaan

pelanggaran terhadap UU

5/1999.

Berdasarkan laporan

hasil monitoring yang

dilakukan oleh tim

monitoring terdapat adanya

dugaan tindakan

pemblokiran terhadap

Sambungan Langsung

Internasional (selanjutnya

disebut SLI) kode akses

001 dan 008 milik PT.

Indosat. PT. Telkom telah

melakukan perjanjian

dengan penyelenggara

warung telkom yang memuat klausula yang

berakibat pada tidak

tersedianya jasa telepon

internasional selain produk

jasa PT. Telkom. ${ }^{23}$ Perihal

tertutupnya akses SLI-001,

pada akhir tahun 2001,

muncul keluhan PT.

Indosat atas tertutupnya

akses SLI 001 bagi

konsumen atau pengguna

telepon lokal PT. Telkom

yang ingin mengadakan

komunikasi telepon

internasional yang terjadi

di sejumlah wilayah

nasional Indonesia yang

meliputi konsumen atau

pengguna telepon di jenis

residensial, bisnis serta
${ }^{23}$ Isis Ikhawansyah, Man S Sastrawidjaja, Rahmi Yuniarti, Hukum Perusahaan Analisis Privatiasasi BUMN dalam Hukum Persaingan Usaha Tidak Sehat, PT Refika Aditama, Bandung, 2019, hlm. 54. 
Wartel. $^{24} \quad$ Tertutupnya

akses telepon internasional

terjadi ketika pengguna

atau pelanggan telepon

hendak ke luar negeri

(outgoing) dan tidak terjadi

untuk penerimaan telepon

dari luar negeri ke

domestik (incoming). ${ }^{25}$

Tim monitoring

menyimpulkan bahwa

Terlapor diduga melanggar

Pasal 18, Pasal 19, dan

Pasal 25 UU 5/1999.

Terjadinya pelanggaran

ketentuan Pasal pada UU

No.5 tahun 1999 oleh PT.

Telkom sebagai BUMN

yang menunjukan bahwa

BUMN (PT.Telkom)

belum sepenuhnya mewujudkan hakikat Pasal

51 UU No. 5 tahun 1999 , hal ini juga menunjukkan masih rendahnya budaya hukum

BUMN

(PT.Telkom Indonesia)

dalam menjalankan

amanah Pasal 33 ayat (2)

UUD 1945 jo UU 19 tahun

2003 jo. UU 5 tahun 1999

yakni mewujudkan

kesejahteraan umum.

Pelanggaran terhadap UU No. 5

tahun 1999 harus ditangani secara

serius oleh KPPU sebagai aparat

penegakan hukum UU 5 tahun 1999.

Praktiknya ternyata peran KPPU

sebagai aparat penegakan hukum UU

No. 5 tahun 1999 masih belum

optimal, hal mana karena masih

lemahnya wewenang dan fungsi KPPU

itu sendiri. Wewenang KPPU perlu

dibuat secara komprehensif, dengan

${ }^{24}$ Ibid, hlm. 54-55.

${ }^{25}$ Ibid. 
demikian apabila wewenang KPPU

telah komprehensif dengan stimultan

maka sanksi terhada BUMN yang

terbukti melakukan pelanggaran

terhadap UU No. 5 tahun 1999 dapat

berakibat positif yang tentunya dapat

meningkatkan budaya hukum BUMN.

KPPU sebagai aparat penegak

hukum dari pelaksanaan pelaksanaan

UU 5 tahun 1999 dirasa masih

memiliki kewenangan yang masih

terbatas. wewenang KPPU

berdasarkan Pasal 36 UU 5 tahun 1999

adalah sebagai berikut :

1. Menerima laporan dari masyarakat dan atau dari pelaku usaha tentang dugaan terjadinya praktik monopoli dan atau persaingan usaha tidak sehat.

2. Melakukan penelitian tentang dugaan adanya kegiatan usaha dan atau tindakan pelaku usaha yang dapat mengakibatkan terjadinya praktik monopoli dan atau persaingan usaha tidak sehat.

3. Melakukan penyelidikan dan atau pemeriksaan terhadap kasus dugaan praktik monopoli dan atau persaingan usaha tidak sehat yang dilaporkan oleh masyarakat atau oleh pelaku usaha atau yang ditemukan komisi sebagai hasil penelitiannya.

4. Menyimpulkan hasil penyelidikan dan atau pemeriksaan tentang ada atau tidak adanya praktik monopoli dan atau persaingan usaha tidak sehat.

5. Memanggil pelaku usaha yang diduga telah melakukan pelanggaran terhadap ketentuan UU No. 5 Tahun 1999.

6. Memanggil dan menghadirkan saksi, saksi ahli, dan setiap orang yang dianggap mengetahui

pelanggaran ketentuan UU No. 5 Tahun 1999.

7. Meminta bantuan penyidik untuk menghadirkan pelaku usaha, saksi, saksi ahli, atau setiap orang yang dimaksud dalam nomor 5 dan 6 tersebut di atas yang tidak bersedia 
memenuhi panggilan Komisi.

8. Meminta keterangan dari Instansi Pemerintah dalam kaitannya dengan penyelidikan dan atau pemeriksaan terhadap pelaku usaha yang melanggar ketentuan UU No. 5 Tahun 1999.

9. Mendapatkan, meneliti, dan atau menilai surat, dokumen atau alat bukti lain untuk keperluan penyelidikan atau pemeriksaan.

10. Memutuskan dan menetapkan ada atau tidak adanya kerugian di pihak pelaku usaha lain atau masyarakat.

11. Memberitahukan putusan Komisi kepada pelaku usaha yang diduga melakukan praktik monopoli dan atau persaingan usaha tidak sehat.

12. Menjatuhkan sanksi berupa tindakan administratif kepada pelaku usaha yang melanggar ketentuan UU No. 5 Tahun 1999.

Berdasarkan wewenang KPPU tersebut dalam Pasal 36 UU No. 5 tahun 1999, KPPU hanya berwenang menjatuhkan sanksi administratif kepada pelaku usaha (termasuk BUMN) yang terbukti melakukan pelanggaran UU No 5 tahun 1999, padahal sanksi yang dapat dijatuhkan kepada pelaku usaha (termasuk BUMN) yang terbukti melakukan pelanggaran terhadap ketentuan UU No 5 tahun 1999 selain administratif adalah juga sanksi pidana. Sanksi pidana dapat dikenakan ketika BUMN atau pelaku usaha lainnya yang telah diputus bersalah melakukan pelanggaran UU No 5 tahun 1999 dan dijatuhkan sanksi administratif akan tetapi yang bersangkutan tidak menjalankan sanksi administratif itu. Dihubungkan dengan kewenangan KPPU sebagaimana diatur Pasal 36 UU No 5 tahun 1999, tidak jelas dan tidak diatur bagaimana penegakan sanksi pidana. KPPU tidak dapat 
menegakan sanksi pidana karena KPPU tidak diberi wewenang untuk itu. Terdapat kekosongan hukum yang nyata terkait dengan bagaimana pelaksanaan dan penegakan sanksi pidana terhadap BUMN/pelaku usaha lainnya yang terbukti melanggar UU 5 tahun 1999 dan tidak menjalankan sanksi administratif. Adanya kekosongan hukum dalam UU 5 tahun 1999 tersebut menunjukan "faktor hukumnya" sedikit banyak membawa akibat tidak terwujudnya efektifitas penerapan UU 5 tahun 1999.

\section{Penutup}

Berdasarkan uraian tersebut diatas, maka penulis mendapat kesimpulan :

1. UU No. 5 Tahun 1999 tentang Larangan Praktik Monopoli dan Persaingan Usaha Tidak Sehat hakikatnya mengikat setiap pelaku usaha dalam kegiatan usahanya, dengan pertimbangan untuk mewujudkan kesejahteraan umum, berdasarkan Pasal 51 UU No. 5 Tahun 1999, BUMN sebagai salah satu pelaku usaha diberikan pengecualian tertentu terkait penerapan UU No. 5 tahun 1999 dalam kegiatan usahanya. Pemenuhan beberapa kriteria pengecualian terhadap BUMN terdapat pada Pedoman Pelaksanaan Pasal 51 UU No. 5 Tahun 1999, jadi tidak semua BUMN diberikan hak monopoli berdasarkan Pasal 51 UU No. 5 Tahun 1999. Diberikan hak monopoli kepada BUMN membawa pengertian bahwa pengelolaan kegiatan monopolinya pun harus dipertanggungjawabkan pada pemerintah. Sifatnya tidak semata-mata mencari 


\begin{tabular}{|c|c|}
\hline keuntungan. Peran penting yang & hukum \\
\hline BUMN & Telekomunikasi \\
\hline perekonomian nasional guna & BUMN \\
\hline mewujudkan kesejahteraan rakyat & mewujudkan tujuan UU No. \\
\hline tetap menjadi tujuan pokok dari & tahun 1999 jo UU 19 tahun 2003 \\
\hline kegiatan usaha yang dijalankan & yakni mewujudkan kesejahteraan \\
\hline BUMN. & umum, serta masih terdapatnya \\
\hline Masih terdapatnya pelanggaran & kekosongan \\
\hline terhadap ketentuan UU No. 5 & keterbatasan kewenangan \\
\hline tahun 1999 tentang Larangan & penegakan \\
\hline Praktik Monopoli dan Pesaingan & administratif maupun pidana dalam \\
\hline Usaha Tidak Sehat oleh BUMN & UU No. \\
\hline sebagaimana dilakukan oleh & menyebabkan UU No. 5 tahun \\
\hline PT.Telkomunikasi & 1999 belum sepenuhnya berlaku \\
\hline Tbk dalam perkara nomor: & efektif terhadap kegiatan usal \\
\hline 02/KPPU-I/2004 & yang dilakukan BUMN. \\
\hline
\end{tabular}

\begin{tabular}{|c|c|}
\hline Penyelenggaraan & DAFTAR PUSTAKA \\
\hline Langsung Internasional (SLI) & A. Buku \\
\hline Telekomunikasi & \\
\hline tidaknya dalam kasus tersebut & $\begin{array}{c}\text { Abdulkadir Muhammad, Hukum dan } \\
\text { Penelitian Hukum, PT Citra } \\
\text { Aditya Bakti, Bandung, } 2004\end{array}$ \\
\hline menunjukan masih rendahnya & $\begin{array}{c}\text { Devi Meyliana, Hukum Persaingan } \\
\text { Usaha :Studi Konsep }\end{array}$ \\
\hline
\end{tabular}


Pembuktian Terhadap

Perjanjian Penetapan Harga dalam Persaingan Usaha, Setara Press, Malang, 2013.

Elly Erawaty, Pengantar Hukum

Ekonomi Indonesia, Fakultas

Hukum Universitas Katolik

Parahyangan, Bandung, 2011.

Kompilasi Hukum Bisnis dalam

Rangka Purnabakti

Prof.Dr.H.Man

Sastrawidjadja. S.H.,S.U.,

CV.Keni, Bandung, 2012.

Isis Ikhawansyah, Man S Sastrawidjaja, Rahmi Yuniarti, Hukum Perusahaan Analisis Privatiasasi BUMN dalam Hukum Persaingan Usaha Tidak Sehat, PT Refika Aditama, Bandung, 2019.

Isis Ikhwansyah, Hukum Persaingan Usaha dalam Implementasi Teori dan Praktik. : Unpad, Press Bandung, 2010.

Janus Sidabalok, Hukum Perusahaan Analisis terhadap Pengaturan Peran Perusahaan dalam Pembangunan Ekonomi Nasional di Indonesia., Nuansa Aulia, Bandung, 2012.
Soerjono Soekanto, Faktor-Faktor yang Mempengaruhi Penegakan Hukum, PT. Raja Grafindo Persada, Jakarta, 2008.

Sunaryati Hartono, Hukum Ekonomi Pembangunan Indonesia, Binacipta, Bandung, 1988.

\section{B. Perundang-Undangan}

Undang-Undang Dasar Negara Republik Indonesia 1945

Undang-Undang Nomor 5 Tahun 1999 tentang Larangan Praktik Monopoli dan Persaingan Usaha Tidak Sehat

Undang-Undang Nomor 19 Tahun 2003 tentang Badan Usaha Milik Negara

Keputusan Presiden Nomor 75 Tahun 1999 tentang Komisi Pengawas Persaingan Usaha

Peraturan Komisi Pengawas Persaingan Usaha Nomor 1 Tahun 2010 tentang Tata Cara Penanganan Perkara

\section{Sumber Lainnya}

www.hukumonline.com 
